\title{
NURSES' PERCEPTION CONCERNING THE CARE FOR PATIENTS WITH PHYSICAL DISABILITIES THAT INTERFERE WITH SELF-IMAGE: A PHENOMENOLOGICAL APPROACH
}

\author{
Karin Kalita de Oliveira Pinto ${ }^{1}$
} Wilza Carla Spiri

Pinto KKO, Spiri WC. Nurses' perception concerning the care for patients with physical disabilities that interfere with self-image: a phenomenological approach. Rev Latino-am Enfermagem 2008 maio-junho; 16(3):407-13.

This study aimed at understanding the perception and the meaning of caring for patients with selfimage problems resulting from physical alterations to nurses working at a university hospital. Phenomenology was the methodology used, and the subjects of study were eight nurses. In order to analyze the statements given, transcription and readings were performed, seeking for the essence of the units, the expression of meanings by thematizing and interpreting the discourse and looking for convergence, divergence, idiosyncrasies and synthesis of the phenomenon. The unveiled themes were: (non) Acceptance of the disease; Team work; Limitations resulting from the disease; The nurse's and team's feelings and behavior; Ties between the team, patient and family; The family; Patient's self-image; Patients' age; Prejudice; Acknowledgement or knowledge of the disease; Care level and more intense care; Religion and Capacitation. Due to the amplitude of the phenomenon, other angles can be unveiled and other perspectives can be inhabited.

DESCRIPTORS: self-concept; nursing care; qualitative research

\section{LA PERCEPCIÓN DE ENFERMEROS SOBRE EL CUIDADO DE PACIENTES CON PROBLEMAS FÍSICOS QUE INTERFIEREN EN LA AUTOIMAGEN: UN ABORDAJE FENOMENOLÓGICO}

El presente estudio tiene como objetivo comprender la percepción y el significado de cuidar de pacientes con problemas de autoimagen, resultantes de una alteración física, por enfermeros de un Hospital Universitario. La trayectoria metodológica fue la fenomenología, los sujetos de la investigación fueron ocho enfermeros. Para analizar las declaraciones, se realizaron la trascripción y las lecturas, buscando encontrar la esencia de las unidades, la expresión de los significados de los temas e interpretando los diálogos, buscando convergencias, divergencias e idiosincrasias y la síntesis del fenómeno. Los temas revelados fueron: La no aceptación de la enfermedad; el trabajo en equipo; las limitaciones como consecuencia de la enfermedad; los sentimientos y comportamiento del enfermero y del equipo; el vínculo entre el equipo, el paciente y la familia; la familia; la autoimagen del paciente; la edad de los pacientes; el prejuicio; el reconocimiento de la enfermedad; el nivel y los cuidados intensivos; la religión y la capacitación. Por la amplitud del fenómeno, se sugiere el estudio de otras perspectivas.

DESCRIPTORES: autoimagen; atención de enfermería; investigación cualitativa

\section{A PERCEPÇÃO DE ENFERMEIROS SOBRE O CUIDAR DE PACIENTES COM PROBLEMAS FÍSICOS QUE INTERFEREM NA AUTO-IMAGEM: UMA ABORDAGEM FENOMENOLÓGICA}

O presente estudo tem como objetivo compreender a percepção e o significado do cuidar de pacientes com problemas de auto-imagem, resultantes de alteração física, por enfermeiros de um hospital universitário. A trajetória metodológica foi a fenomenologia, os sujeitos da pesquisa foram oito enfermeiros. Para a análise dos depoimentos, realizou-se a transcrição e as leituras, buscando a essência das unidades, expressão dos significados, tematizando e interpretando as falas, buscando convergências, divergências e idiossincrasias e a síntese do fenômeno. Os temas desvelados foram: (não)aceitação da enfermidade; trabalho em equipe; limitações conseqüentes da doença; sentimentos e comportamento do enfermeiro e equipe; vínculo entre equipe, paciente e família; a família; auto-imagem do paciente; idade dos pacientes; o preconceito; (re) conhecimento da doença; nível e cuidados mais intensos; a religião e capacitação. Pela amplitude do fenômeno outros ângulos podem ser desvelados e outras perspectivas habitadas.

DESCRITORES: auto-imagem; cuidados de enfermagem; pesquisa qualitativa

${ }^{1}$ Undergraduate student, at Sao Paulo State University "Júlio de Mesquita Filho", Brazil, e-mail: trolla_enf@yahoo.com.br; ${ }^{2}$ PhD, Faculty at Sao Paulo State University "Júlio de Mesquita Filho", Medical School at Botucatu, Brazil, e-mail: wilza@fmb.unesp.br 


\section{INTRODUCTION}

This study takes into account the apprehension concerning the care given to patients presenting some type of physical disability that may interfere with their self-image. It was conducted with patients of a university hospital who were previously physically sound and, due to accidents or disease, suffered visible body alterations resulting in some type of disturbance and/or derangement to their selfimage.

Body image is the mental figure or perception that one forms or has of his own body ${ }^{(1)}$.

We believe that different ways exist for coping with the acceptance of one's body image. Some easily cope with it and are able to proceed with their lives without trauma; others cannot accept the change at first, but eventually learn to live with that which is inevitable. There are also those who cannot deal with their limitations, and it is in the latter two cases, in particular, that we understand the importance of a study aiming at what and how much the nurse can perceive as regards this situation.

In the relationship established between people with a disability and those without, there is the intense presence of feelings, such as fear, anger, grief, attraction, and repugnance. These feelings may occur conjointly or separately and may be strong or moderate; nevertheless, they are frequent and real ${ }^{(2)}$.

These feelings occur in families, professionals and in any individuals who, when facing disability directly or indirectly, present some type of "psychological suffering". There is a negation process by means of thoughts, words and actions ${ }^{(2)}$.

Biological deviance in the human body is manifested by the "lack or excess of". The disabled individual is the very personification of asymmetry, unbalance and dysfunctions. Hence, his disfigurement intrinsically threatens the bases of the other's existence. The other, the different and disabled one represents the awareness of the very imperfection of the one who sees and mirrors his limitations and emasculation. He also represents the survivor; the one who has been through a catastrophe and survived, thus beckoning with the potential catastrophe which is virtually suspended upon the other's life. Additionally, he represents a narcissistic wound in each professional, in each community. He represents an undisguisable conflict which is explicit in each interrelation dynamics. He represents, from anywhere that he is looked at, a wound in idealized alabaster skin. He represents a threat and danger ${ }^{(3)}$.
It is through his body image that an individual maintains his inner balance while he interacts with the world $^{(1)}$.

When an individual, at a certain moment, does not accept his body as it is, unbalance may occur, thus triggering self-image disturbance. The nursing professional must recognize such self-image crisis, which may be shown both orally and non orally, and is subdivided into four phases: shock, negativism, acknowledgement of reality and adaptation ${ }^{(4)}$.

Some symptoms may be indicative of the selfimage crisis. The individual may be plaintive, quiet, depressed, (sad, abated, melancholic), hostile (angry, irritated), fearful, negativist and anxious. He may present specific pain or not, anorexia, insomnia, and may be questioning, digressing, crying, agitated, among other symptoms ${ }^{(4)}$.

Non acceptance of one's own appearance leads the individual to believe that those around him will not accept him either, which may cause depression related to the dissatisfaction about one's appearance and low self-esteem. Through esthetical procedures, individuals who do not live satisfactorily with their appearance alleviate their anxieties ${ }^{(5)}$.

Nursing care for patients with self-image problems includes: "basic knowledge concerning the self dimension and its inter-relations; consideration so that, in each activity, that which composes the individual's self-image core is observed; distinction of the crisis phases; helping the patient to remain within normality levels; identifying symptoms and signs indicating unbalance; helping the patient to recover normal levels; consideration for human beings as bio-psycho-social units in constant balance in time and space; establishment and maintenance of a therapeutic relationship; the nurse as an instrument of observation and communication."(4).

Individuals with problems in appearance who can count on social and family support are able to deal with such situation more easily and get rid of prejudice that may arise. Hence, the nurse plays a relevant role, since attitudes such as stimulating the expression of feelings allows for adequate care planning $^{(6)}$

\section{OBJECTIVE}

Understanding the perception and meaning of caring for patients with self-image problems resulting from physical disability to nurses working in a university hospital. 


\section{METHODOLOGY}

Phenomenology was used to reveal the phenomenon, that is, seeking for the essence, the meaning of the reality experienced by the subjects under study, aiming at understanding it. The course followed consisted of three moments: description, reduction and comprehension.

Description comprises three elements: perception, conscience and the subject ${ }^{(7)}$. We collected the statements aiming at the studied subjects' perception of the meaning produced by the conscience of caring for patients with self-image problems related to visible physical disability.

Phenomenological reduction aimed at determining and selecting which parts of the description were considered to be essential. From the collected and transcribed statements, reduction was performed by pondering over the discourse and extracting its essence.

Phenomenological comprehension specified the "meaning" which was essential in description and reduction as a way to investigate the experience. Based on the essence and the subjects' discourse, the revealed themes were organized and interpreted, thus making a synthesis of the meaningful units found and their convergence, divergence and idiosyncrasies.

The inquiry region of the study consisted of the situation experienced by nurses at a university hospital who gave care to patients with self-image problems resulting from physical alteration.

The investigated subjects were defined during the study and totaled eight nurses whose statements were enough to unveil the essence of the phenomenon under study.

The project was approved of by the Ethics Committee of the Botucatu School of Medicine UNESP, and nurses assisting adult patients were identified in the Nursing Division. They participated in interviews and agreed to participate in the study by signing an Informed Consent Form.

The interviews were conducted on the sites chosen by the subjects and tape recorded. After transcription, the tapes were destroyed. The following guiding questions were asked:

- How do you perceive the patient(s) who has (have) self-image problems? What does giving care to such patient(s) mean to you?

\section{CONTRUCTION OF RESULTS}

The unveiled themes refer to the essence of the situation experienced by the subjects.

The theme (non) acceptance of the disease showed distinct aspects in relation to the nurse's perception as regards the patient's acceptance of his disease or limitation, varying from patients who accepted their new condition, or at least were easily adapted to it, to those who presented considerable difficulty in accepting their new reality.

Regardless of the level of acceptance shown

by patients, time arose as a point of utmost importance for them to accept themselves better and become used to living with their new condition. Hence, it was perceived that the beginning of shock, depression, sorrowfulness and denial, among others, were remarkable feelings shown by the patient. After some time, acceptance was then observed by some whereas it was more difficult to others.

Upon the onset of the disease, the individual tends to live in homeostasis, suffers unbalance, and this crisis situation requires that he recovers balance. The disease is generally regarded as threatening and limiting; it generally causes anxiety and requires effort coping with ${ }^{(8)}$.

Family support to the patient was also shown to be a fundamental aspect for recovery and disease acceptance for when the family is present, the patient presents signs of improvement and overcoming.

Social support and family support in particular enable people to cope with their problems more easily by alleviating pain and suffering, reducing anxiety and depression and making them more emotionally stable ${ }^{(9)}$.

Help from a specialized professional, such as a psychologist, is sometimes necessary when the patient, even after some time, still presents difficulty in accepting and living with his new condition.

Nurses admit that healthcare giving is mostly collective work that is performed by various healthcare professionals. Psychologists participate in the team and, in a multidisciplinary perspective, the complexity of problems allows for such cooperation action and for the disruption of a fragmented view of healthcare ${ }^{(10)}$.

Patients who suffer the most and negate their reality are the youngest ones and those who have been taken by a disease that intensively affects appearance. 
By risking making a reductionisitc analysis, it can be assumed that the younger individuals are constructing their body image, and in this construction process, aspects concerning social relations are fundamental for "our body image is our totality as human beings"(11).

As regards the theme team work, the statements unveiled that the patient priorly requires attention, affection and respect for the moment that he is experiencing and his anguish. Strategies such as conversation, guidance, equal treatment, in addition to stimulus, encouragement and incentive to self-care are used by the nursing staff so that the patient can realize and believe in the possibility of resuming life as normally as possible within his limitations, including the possibility of resuming life independently within his present conditions.

The work is done by reinforcing the patient's healthy aspects and that treatment is not only based on his disease and limitation. The objective is to give patients and their families humanized and optimized care so that recovery can be as good as possible.

Team work is essential for the integral approach to healthcare. However, we must not be so naïve as to believe that the care team will be exempt from conflicts since a team does not mean harmony, but rather the acknowledgment and dialogical facing of all sorts of differences, inequalities and difficulties that permeate work routine ${ }^{(12)}$.

Still in the perspective of team work, interaction is fundamental, and dialogue, respect, collaboration, common objectives, trust, ethics, creativity, competence and humbleness are presuppositions that consolidate this work.

The theme limitations and outcomes resulting from the disease unveiled that when limitations abruptly affect the patient, they produce depressive behaviors with saddening and situational negation aspects which differ from those of patients affected by gradual limitation.

Acknowledging and understanding the limitations and losses imposed by the disease allow for adaptations and imply dealing with the occurring changes. In this aspect, the subjects in the study acknowledged how much support can possibly be provided by healthcare professionals, family members and other social networks in which the patient participates $^{(8)}$.

The analysis of the statements related to the theme the nurse's and team's behaviors showed that professionals frequently manifest signs of sadness, are sensitive to the patient's condition, often cry and are concerned about post-discharge care, thus confirming the statements that patients with self-image problems cause anxiety in healthcare professionals as well as a stressful and worrisome atmosphere, since the staff shares the patient's and his family's suffering and shows them sympathy.

The feelings expressed by the nurses are relevant. Their expression enables those professionals to acknowledge themselves as human beings, since the relationship with the disease and its manifestation in people needs to be made explicit among staff members so that feelings can be healthily dealt with, "... the disabled person is the very personification of asymmetry... hence his disfigurement and mutilation intrinsically threaten the bases of the other's existence...", analogously, a person with self-image alteration stemming from the disease also causes estrangement to those around him, and this includes healthcare professionals ${ }^{(2)}$.

On the other hand, the professionals try not to transmit their suffering and anguish to the patient. They always attempt to encourage him to resume his life to normality, taking his new condition into account. Additionally, they are careful so as not to allow such personal feelings to interfere with their private lives and, depending on the tie with the patient, professionals also require help so that their feelings can be properly dealt with, thus not interfering with their personal lives or hindering the patient's treatment.

As regards the theme tie between the staff, patient and family, it was understood that an affective tie is formed between those involved with the patient; however, caution is taken so that such feelings awakened in individuals will not interfere with or hinder the nursing staff's work. Feelings of sadness, and many times crying episodes, strike professionals depending on the tie formed and on the patient's situation, and there is always a concern about the continuation of adequate treatment after hospital discharge and about home care.

The establishment of ties is fundamental for professional relationship for "... it is only in this way that real equality with respect for the other's differences and weaknesses can be established. If inequality stems from the other's debility and suffering, it is compassion that tends to re-establish reciprocity. It also true that "the one who seems to 
only give receives more when he does so, in the form of gratitude and acknowledgment"(12).

As concerns the theme family, the statements unveiled that family members, many times, show more suffering and depression than their diseased relative. There are situations in which the patient's incapacity to understand his pathological state hinders the expression of his feelings and causes anxiety in his family. The family thus requires psychological support as its members will need to live with a disabled relative.

The staff works with the family aiming at reducing anxiety while giving care to the patient. The family is offered training prior to the patient's discharge from hospital so that home care can be properly given. The subjects reported the importance of family proximity to patients, since they present signs of improvement and faster recovery when the family is present and supportive.

Family support is essential for recovery, and the family plays a major role in the patient's reinsertion into his social milieu. Additionally, the family is not immune to the situation experienced by his dear one and needs to be given support and home care conditions by the nursing staff.

Concerning the patient's self image, it was noticed that giving care to patients who manifest selfimage problems is a challenge, since there is a contradiction in feeling expression. Some show feelings that are regarded as negative, such as sadness, anguish, aggressiveness and depression while others are not able to clearly express such feelings as emotions are exacerbated and different for each moment of experiencing the disease.

There is a body image involved which supports the conception that an individual has of his personality and of his relationship with others. The image constructed in childhood is deeply inserted in one's global psychic functioning, which contributes to emotional reactions in view of body alterations resulting from disease, lesions or organ loss ${ }^{(1,8)}$.

Another apprehended aspect revealed that the limitation resulting from disease causes mild suffering when compared to the fact that the patient is alive, or also that the severity of the cured problem, although resulting in an alteration that interferes with self-image, is relativized and accepted with resignation.

This theme also includes the nurse's perception of his professional role incorporated by the holistic view and his concern about encouragement, despite his acknowledgement of the fact that the experience is traumatic to the patient and his relatives. Also, it includes the nurse's concern about valuing the patient's initiatives to resume life with tranquility and his acceptance of self-image.

Help from competent professionals in undoubtedly necessary for the patients, who, in case they lack support, may be blocked by the negation of their present condition.

The theme patients' gender and age showed that both males and females of different ages suffer self-image alteration; however, it also revealed that young people and particularly females are the ones with most difficulty to overcome and accept the limitation as a new reality.

Although there presently is a movement by males towards the "cult of the body", as to this aspect, females are more susceptible to social repercussion of self-image alteration. Body image is not only a cognitive construction, but also the reflection of desire, emotional attitudes and interaction with others, and this is blocked ${ }^{(11)}$.

We believe that this concept, many times implicit and unexpressed, permeates thought and action, particularly that of patients who experience disease. As to this aspect, the nurses in the study were sensitive enough so as to perceive this meaning.

Prejudice was also unveiled when the nurses reported that patients with physical alteration interfering with their self-image were victims of social and family prejudice. There is also prejudice among patients themselves during the hospitalization period. As a form of defense from such prejudice, they escape from the family environment and take refuge in the hospital through hospitalization. The need for respect for patients so that they will not suffer any type of prejudice or discrimination due to their condition is then perceived.

In this respect, prejudice is by definition a previous attitude to any knowledge and, therefore, lacks foundation. Physical alteration and its resulting limitation may trigger prejudice and stereotypes. Prejudice may cause aversion or a commiseration attitudes to the individual, both of which are devoid of coping and generate conflicts, as perceived and made explicit by the nurses. It is important to consider that the minimization of the patient's coping with his condition and his acceptance by the professionals assisting him are made possible by the refuge taken in hospitalization ${ }^{(2)}$. 
Acknowledgment and knowledge of the disease showed that it is primarily important to observe whether the patient knows exactly what is happening to him and his diagnosis.

By taking into account the bioethics frameworks, the patient has the right to the truth, which does not simply mean a cold communication of data and objective information, since time opportunity and appropriate conditions are necessary. The nurse, as a member of a multidisciplinary team who spends the most time with the patient, can provide himself with empathy and prudence in order to adapt to each patient's need, thus helping him to take hold of his own truth. Once this is said, we apprehended that the nurse is concerned about knowing whether the patient is aware of his diagnosis and its implications in his life $\mathrm{e}^{(13)}$

As regards care level and more intense care, it was shown that patients with self-image problems made the nursing staff's work more tiresome due to greater care complexity. Therefore, more staff is necessary for nursing care giving.

Over the years, studies on nursing staff estimation have been the focus of attention of nurses and healthcare service managers, since it directly interferes in the efficacy, quality and cost of healthcare: "giving care to clients with increasingly complex needs has posed an overload of work on nursing staff members, thus influencing and hindering the implementation of any measures that may favor the quality of the care given"(14). This statement leads us to consider that the nurse's perception concerning his tiresome work has a direct implication in care complexity and ever increasing demands.

Religion was also revealed as a topic and expressed the importance of the existence of some type of belief for the patients' recovery and acceptance in relation to their new reality. They show more enthusiasm and ease for overcoming their selfimage-related problem.

"Religion arises as a guarantee of survival and symbolic protection, providing support to those who suffer and comfort to those who $\mathrm{cry}^{\prime \prime}(9)$.The nurse perceives the importance of this relationship and when he can contribute to acceptance of the disease as well as to hope for cure.

The theme capacitation unveiled that some professionals do not feel prepared to deal with patients who do not accept their self-image and their new condition. They feel insecure to approach and communicate with the patient and his family as regards the situation experienced, considering the new reality presented and the delicate moment at which this relationship is established.

Nurses working with disabilities gradually become capable for the work through experience, contact and theoretical knowledge. In the nurse's relationship with the family and the patient, feelings of anxiety, insecurity, negation and rejection are noticed, and they result in emotional involvement ${ }^{(15)}$.

\section{FINAL REMARKS}

When unveiling the essence of the phenomenon concerning the meaning of giving care to patients with self-image problems resulting from physical alteration, the statements produced convergence, divergence and idiosyncrasies which enabled the understanding of nurses' perception of giving care to patients who may present self-image problems due to physical limitation resulting from disease and/or accidents.

The meaning attributed by the subjects apprehends the need for a nursing team that is well prepared and oriented to give adequate patient care and which believes that the team also requires attention and care to deal with the feelings awakened by caring for such patients. The formation of ties occurs among the individuals involved; nevertheless, there is a concern about not allowing interference from work with their personal lives.

It was understood that patients and their family members require encouragement to resume life according to their limitations, and that time was the support for specialized professionals and religion facilitated this process.

With regard to self-image, it was unveiled that the feelings manifested buy the patients were regarded as negative in view of their condition, in addition to felt prejudice. Younger patients and particularly females showed more resistance to accepting their limitation.

Work is tiresome and stressful to the nursing staff; therefore, more human resources are necessary for patient's humanized and optimized care.

Given the amplitude of the phenomenon, other perspectives are contemplated and other approaches can be made. New disclosures consider the unlimited horizons of human beings. 


\section{REFERENCES}

1. Santos VLG, Sawaia BB. A bolsa na mediação "estar ostomizado" - "estar profissional" análise de uma estratégia pedagógica. Rev Latino-am Enfermagem 2000 julho; 8(3):4050 .

2. Amaral LA. Corpo Desviante/ Olhar Perplexo. Psicol USP 1994; 5(1/2):245-68.

3. Amaral LA. Do Olimpo ao mundo dos mortais. São Paulo (SP): Edmetec; 1988.

4. Koizumi MS. O atendimento da enfermeira em relação à necessidade de auto- imagem. Enferm. Novas Dimens 1975; $1(2): 69-74$.

5. Auricchio AM. Procedimentos estéticos: percepção do cliente quanto ao esclarecimento para a tomada de decisão [Dissertação]. São Paulo: Universidade de São Paulo; 2004. 6. Carlowe J. Facial disfigurement. Nurs Times 1997; 93(42):34-5.

7. Merleau-Ponty M. Fenomenologia da percepção. São Paulo (SP): Martins Fontes; 1994.

8. Martins G, Cunha S, Coelho R. A auto-actualização como motivação para a aceitação da doença. Rev Port Psicossomática 2005; 7(1/2):115-23.

9. Pietrukowicz MCLC. Apoio social e religião: uma forma de enfrentamento do problema da saúde [Dissertação]. São Paulo: Escola Nacional de Saúde Pública, Fundação Oswaldo Cruz; 2001.

10. Pires D. A estrutura objetiva do trabalho em saúde. In: Leopardi, MT, Kirchhof AL, Capella BB, Pires D, Faria EM, Ramos FRS. O processo de trabalho em saúde: organização e subjetividade. Florianópolis (SC): Papa-Livros, 1999. p.2555.

11. Barros DD. Imagem corporal: a descoberta de si mesmo. Hist Ciênc Saúde - Manguinhos. 2005; 12(2):547-54.

12. Spiri WC, Leite MMJ. O significado do trabalho em equipe na reabilitação de pessoas com malformação craniofacial congênita. Rev Esc Enferm USP 2004; 38(3):288-97.

13. Spiri WC, Berti HW, Pereira MLD. Os princípios bioéticos e os direitos dos usuários de serviços de saúde. O Mundo da Saúde. 2006; 30(3):448-54.

14. Gaidzinski RR, Fugulin FMT, Castilho V. Dimensionamento de pessoal de enfermagem em instituições de saúde. In: Kurcgant $\mathrm{P}$, coordenador. Gerenciamento em enfermagem. Rio de Janeiro (RJ): Guanabara Koogan; 2005. p.125-37.

15. Spiri WC, Leite MMJ. Convivendo com o portador de fissura lábio-palatal: o vivencial da enfermeira. Rev Esc Enferm USP 1999; 33(1):81-94. 